\title{
A Māori Crisis in Science Education?
}

New Zealand Journal of Teachers' Work, Volume 14, Issue 1, 21-39, 2017

\author{
GEORGINA STEWART \\ ORCID 0000-0001-8832-2415 \\ AUT University
}

\begin{abstract}
This article is written for school teachers in Aotearoa New Zealand schools who teach science to Year 7-10 students or as part of a primary classroom programme under The New Zealand Curriculum. What can teachers do about inequity in science education for Māori students? Clear understanding of this complex issue is required, so this article offers a synopsis of the Mãori science curriculum debate. Written from my perspective as an insider-researcher interested in this topic for many years, this article engages with important comments about Māori-medium science education made by Sir Peter Gluckman in a major report on science education (2011), and an earlier challenge by Graham Hingangaroa Smith (1995) about the 'Māori crisis' in science education. Towards the end I briefly discuss what teachers might do, and consider the potential of 'bilingual science' as an alternate approach with relevance for any classroom teacher, and a way of navigating the current theoretical impasse or 'crisis' in Māori science education.
\end{abstract}

\section{INTRODUCTION}

In a major recent report on science education, Sir Peter Gluckman (2011), in his role as the Chief Science Advisor to the Prime Minister of Aotearoa New Zealand (PMCSA), made a few remarks about Māori science education, and Pūtaiao or Māori-medium science education in particular. These sentences, reproduced in full below, are significant and deserving of attention by Māori science education researchers: they act as inspiration for this article, and suggest the question of Māori science education remains unresolved.

There are particular challenges in the Māori community created by those schools wishing to teach in Te Reo, as the full scope of scientific language is not yet available and there are very few science teachers who are fluent in $\mathrm{Te}$ Reo. It is controversial and well beyond my scope to consider how to address this issue while respecting the wealth of traditional Māori understanding of the natural world. One must ask whether it is a priority to develop a full modern scientific language within Te Reo Māori or 
whether, given the international dominance of English as the basis of teaching and practicing science, teaching of science and mathematics at the senior level in Te Reo schools should use English as the internationally shared language of science. I acknowledge that this is a very difficult issue, but one which I believe Māori educators should consider in some depth. (Gluckman, 2011, p. 7)

Here Gluckman expresses concern about the approach of translating science into Māori, which is the dominant approach in Pūtaiao ${ }^{1}$, and an idea I see attracting increasing support across the education and science sectors. Ironically, projects for producing te reo versions of science texts are among those being funded by the Unlocking Curious Minds funding, set up by MBIE (the Ministry of Business, Innovation and Employment) following Gluckman's report. This widespread support for translating science into Māori, made more 'official' by such funding programmes, logically makes Gluckman's comments relevant, not only to the small number of teachers who are actually teaching Pūtaiao/Science in te reo Māori, but also to all teachers of science and science education researchers in Aotearoa New Zealand.

Gluckman's challenge to Māori science education countered another claim made 16 years earlier by leading Kaupapa Māori scholar, Graham Hingangaroa Smith, in his article on "the Māori crisis within science education" (G. H. Smith, 1995, p. 103), an idea I have borrowed for the title of this article. Smith argued that the Mãori crisis of underachievement in science education had been ignored during decades of constructivist science education research in Aotearoa New Zealand (Osborne \& Freyberg, 1985). Smith challenged science education researchers to stop ignoring this crisis, and predicted that Kura Kaupapa Māori ${ }^{2}$ education would deal with the equity crisis for Māori in science education in coming years.

Two decades on, Smith's prediction turns out to have been overly optimistic: while Pūtaiao development has continued, the initial debates about 'Māori science' (Dickison, 1994; Lomax, 1996; McKinley, McPherson Waiti, \& Bell, 1992) gave way in the 1990s to a dominant policy of translating science into Māori, which remains in place today (Stewart, 2005). I call this approach 'science in Māori-only' and argue that this policy has been contradictory in its effects on the interests of Māori-medium students, while contributing to slow progress in Pūtaiao development (Stewart, 2011b). I agree with Gluckman's comments and concerns, because the efficacy of the translation approach is limited on principle, as well as hampered by severe practical difficulties and ideological constraints, as explained below.

This article starts from these two challenges by leading scholars in the worlds of science and Māori education, and includes advocacy for bilingual science as an option to 'Māori-only' translations. The bilingual science approach keeps what is good, fun and productive about translating science into Māori in

\footnotetext{
${ }^{1}$ Māori-medium science: www.tmoa.tki.org.nz/Te-Marautanga-o-Aotearoa/Nga-Wahanga-Ako/Pūtaiao

${ }^{2}$ Māori immersion schools
} 
the classroom; it still supports Māori student identity in primary and junior secondary science, and it provides a pragmatic alternative to the current policy impasse. This work builds on my previous research and in particular on another article (Stewart, 2017, in press) about the links between Māori science education and the philosophy of the science curriculum. My previous paper is in a special issue on indigenous knowledge (IK), and focuses on Māori-medium science education; conversely, this article is aimed at teachers of Science in English-medium or 'mainstream' classrooms, where most Māori students receive their education.

My research employs CDA (critical discourse analysis) methodology to collect and synthesise key ideas in relevant texts and sources (Locke, 2004). The CDA methodology accommodates a supporting element of autoethnography $(A E)$, in the form of anecdotal knowledge from my own personal and professional experiences (Ellis \& Bochner, 2000). In both methodology and argument, this research is comparable to that undertaken by White Canadian author Alison Sammel, who alternates between a 'Mouse view' and 'Eagle view' (somewhat akin to my 'researcher knowledge' and 'CDA' modes delineated above) to unpack analogous issues for indigenous students in science education in Canada and Australia, concluding "we need to destabilize the foundations of science education by questioning inherent structural and ideological inequities" (Sammel, 2008, p. 855).

This work aligns with Kaupapa Māori research methodology, understood as a critical Māori paradigm for education and other social science research (L. T. Smith, 2012; Stewart, 2016). It is important for the philosophy that underpins and motivates this research to be aligned with Kaupapa Māori research methodology in the interests of Māori students and their whānau (families, communities). Critical understanding of this complex research question concerning Māori science education is urgently required. It is particularly important to align this work with Kaupapa Māori philosophy since my analysis challenges widespread misunderstandings of what Kaupapa Māori means in relation to Māori-medium science education, misunderstandings I previously labelled 'orthodoxies' (Stewart, 2012).

The paradigm of Kaupapa Māori research includes space for a poststructuralist incredulity towards the idea of 'objectivity' in research. Insider research is normal in Kaupapa Māori terms: the researcher is expected to have a personal stake in the research (Pipi et al., 2004). Thus it makes sense to declare my position as researcher-author, in relation to Māori science education. I have several decades of experience and involvement with Pūtaiao education through classroom teaching and teacher education, contract work since 1993 on Pūtaiao curriculum and related projects, my doctoral research (Stewart, 2007) and my subsequent research publications on Māori science education (Stewart, 2010b, 2011a, 2015). The motivation for writing this article was supported by my participation since 2013 in the Science SIG of NZARE ${ }^{3}$.

CDA and $A E$ methodologies are both underpinned by critical and poststructuralist paradigms that permit them to be conscripted into research under the banner of Kaupapa Māori, which underpins the philosophy and ethics

3 www.nzare.org.nz/science-education-research.aspx 
that motivate and direct research decisions. In this article I combine CDA and AE with Kaupapa Māori ethics and paradigm into my version of Kaupapa Māori methodology for research in education. An important disclaimer is to acknowledge that while the inclusion of $A E$ in my methodology is necessary in order to undertake these investigations, its effect is to weaken my claims: my conclusions and recommendations are therefore best considered 'informed opinions' rather than 'the truth.'

The next section reviews the situation of school science education for Māori and presents some evidence from prior studies to support the notion that science is the 'worst-case scenario' for Māori educational achievement, even worse (as most secondary teachers would know) than English or Mathematics.

\section{IS THERE A MĀORI CRISIS IN SCIENCE EDUCATION?}

The Māori inequity in science education hardly qualifies as a 'crisis' in the sense that it is neither new nor a short-term condition: there has been a permanent disparity or gap in school outcomes for Māori, as or more severe in science than in any other subject, since the beginnings of science education in Aotearoa New Zealand, and it remains so today. Māori inequity in school science must be located within the overall picture of educational inequity for Māori, largely resulting from the ethnic gap in literacy and numeracy signalled by the stock phrase 'long brown tail' (Stewart, 2014a). Given the close links between educational outcomes and socio-economic status (Carpenter \& Osborne, 2014), at the statistical level of the Māori population, no other result in education is logically possible, and the gaps will not close unless the SES disparities in our society are reduced. But reducing inequality in society at large would go against current economic trends, in which wealth is being increasingly concentrated in the hands of 'rich-listers' at the expense of everyone else, including most Māori and Pacific students and their families throughout the country. To a large extent, therefore, the Māori 'crisis' or disparity in science education is better understood as a political and economic 'crisis' or, more precisely, a permanent state of relative deprivation as a deliberate planned result of colonisation, which educational inequities inexorably reflect. Within the overall picture of Māori inequity, and given its importance as academic gatekeeper, science education is the 'worst case scenario' for Māori: this was Smith's (1995) point in referring to it as a 'crisis'.

\section{Evidence about Māori science education inequities}

There is very little published data on Māori science education outcomes, but two relevant existing examples are shown below: NCEA ${ }^{4}$ achievement data produced by the Starpath Project ${ }^{5}$ and some data on student attitudes from the New Zealand Council for Educational Research (NZCER) Competent Learners @14 study (Wylie \& Hipkins, 2006).

\footnotetext{
${ }^{4}$ National Certificate of Educational Achievement: the national secondary schools' qualification

${ }^{5}$ www.education.auckland.ac.nz/en/about/research/starpath-home.html
} 

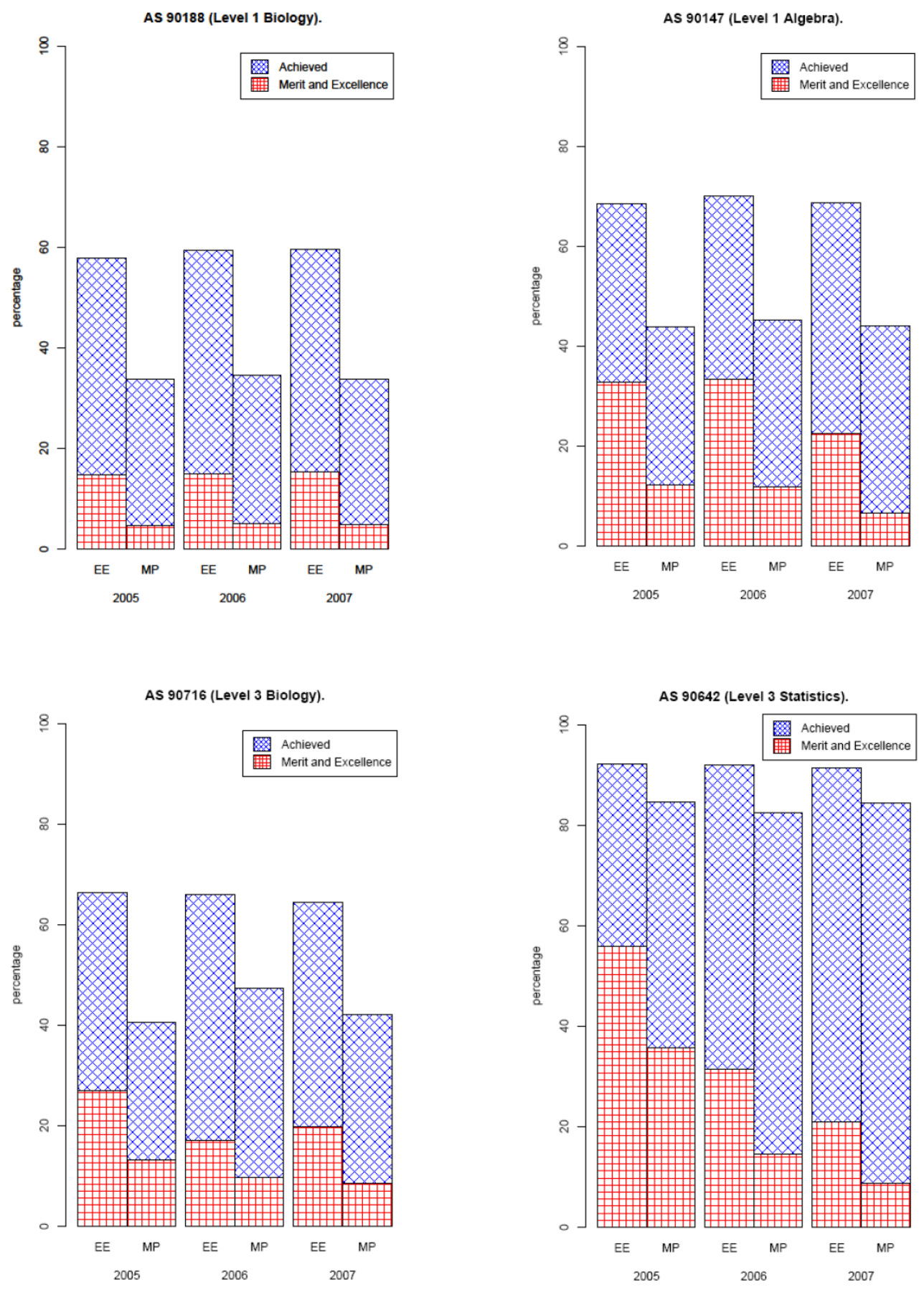

Fig. 1: NCEA Results Data 2005-7 for representative AS in Mathematics and Science

\section{NCEA data}

Figure 1 above contains 4 graphs, originally produced by the Starpath project in 2009, of NCEA data 2005-2007, cut by ethnicity into two groups, Māori and Pacific (MP) and Everybody Else (EE). These graphs illustrate the significant and remarkably consistent disparities in the rates of achievement by 
Māori and Pacific students in four external AS (Achievement Standards, the units of NCEA qualifications), selected to represent NCEA Science and Mathematics:

- 90147: NCEA Mathematics: Level 1 Algebra

- 90188: NCEA Science: Level 1 Biology

- 90642: NCEA Mathematics: Level 3 Algebra

- 90716: NCEA Science: Level 3 Biology

Competent Learners @14

Competent Learners was a longitudinal project undertaken by NZCER for the Ministry of Education. In Competent Learners @ 14, a representative sample of 14-year-old students were asked about the learning environments they experienced in English, mathematics and science classes (Table 1 below). Suggestive trends show up when this data set is filtered for Māori students. This cohort of Māori students said they did not mind asking their teachers questions, and in English and mathematics, most liked their teacher, thought that their teacher treated them fairly and was interested in their ideas. This is a cohort of only 50 Māori students, so the differences seen for Science, compared with English and Mathematics, are not statistically significant, but offer anecdotal support for my arguments in this article. These 50 Māori students were generally less positive about the learning environment (including their relationship with their teacher) in science than in English and mathematics. This pattern is in contrast with that of the whole cohort, where student views of the learning environments in English, mathematics and science classes were broadly similar (Wylie \& Hipkins, 2006).

These data support anecdotal evidence that the gap for Māori is larger in Science than in English or Mathematics, the other two largest academic subjects at senior secondary level. This gap widens over time and is most visible in secondary school, since that is where these three subjects are demarcated and measured. I think this 'extra gap' in science has a philosophical element, which is amenable to change in practice by classroom teachers, but only with the benefit of critical understanding of the issues (Sammel, 2008).

$\begin{array}{llll} & \text { English } & \text { Mathematics } & \text { Science } \\ \text { My teacher knows what interests us } & 40 & 38 & 36 \\ \text { I don't like asking my teacher questions } & 26 & 26 & 20 \\ \text { My teacher is interested in my ideas } & 60 & 56 & 50 \\ \text { My teacher treats me fairly } & 74 & 70 & 58 \\ \text { My teacher really understands how I feel } & 36 & 32 & 18 \\ \text { I like the teacher } & 70 & 60 & 42\end{array}$

Table 1: Percentages of Māori students agreeing with items related to student-teacher relationships $(n=50)$ 
There are no easy or check-list type solutions to the problems of Māori educational inequity, but some suggestions for classroom teachers are listed in the final section below. One serious obstacle to teacher knowledge is that the philosophy of science lies outside 'science' itself, as understood in relation to the school curriculum; so these influences remain hidden and excluded from the professional discourses of science education (Duschl, 1985). The next section examines the theoretical nexus in the philosophy of Māori science education.

\section{THE PHILOSOPHY OF MĀORI SCIENCE EDUCATION}

Even specialist science teachers seldom have any training in philosophy of science, so the philosophical problem influencing their practice remains hidden from the view of teachers, and hence impervious to their efforts. In particular, this problem is not addressed by current policies based on 'culturally responsive/sustaining pedagogies' for teachers of Māori students, which do not include a critical analysis of the specific issues in science (Glynn, Cowie, OtrelCass, \& Macfarlane, 2010). The invisibility of the philosophy of science behind the curriculum prevents teachers from seeing, understanding, and therefore taking effective action against these aspects of the disparity in science outcomes for Māori students in their classrooms.

All knowledge including science is underpinned by a philosophy of knowledge, but the philosophy of science is rarely discussed by scientists in the course of their work, and is not considered part of science itself (Bevilacqua, Giannetto, \& Matthews, 2001). The same is true for the school science curriculum: it is based on a philosophy of science, but one that is hidden and outside the curricular content, and so science education never makes obvious its philosophical commitments. The problem with a philosophy that is implicit rather than explicit, of course, is that it leaves philosophical questions open to interpretation. I conclude that how the philosophy of the science curriculum is understood is a central point around which the longstanding debates about Māori science education revolve.

Where does the philosophy of science come from? To answer this question it is necessary to review the history of science knowledge. The canons of today's 'normal science' have been established over the last three centuries or so, since the period of rapid advances in technology and science in Europe beginning with the Enlightenment, ushered in by philosophers Descartes and Locke in the 17th century (Honderich, 1995). The universalism inherent in Enlightenment thinking underpins modernity overall as a large social era, as well as the development of modern disciplines, including Anthropology and Linguistics, the university itself, science knowledge and institutions, and the formal structures of education, including the curriculum and curriculum theory (L. T. Smith, 2012). Though we may now be in a postmodern era, this does not mean modernity has gone away: it still holds sway, but under different social arrangements from those which pertained in the classical phase of modernity, peaking around 1900 (Peters, 2011).

Most adjectives associated with definitions of 'science' are also associated with definitions of 'modernity', such as objective, logical, naturalistic, etc. Key inventions including the lens and the clockwork mechanism catalysed the age of European Imperialism, which in turn catalysed the inauguration of new paradigms of knowledge in science, from whence a line can be drawn to 
the current state of knowledge in the science disciplines. Science and modernity could be considered to have 'co-evolved' in the conditions of Enlightenment Europe, and both science and modernity are underpinned by philosophical universalism.

Key universalist commitments include that the laws of science and logic apply equally at all times in all places. For this reason science is considered to be free of culture, and essentially democratic. From this perspective, most science teachers reject any claim that science is inherently 'racist'. The problem is that this criterion applies to the cognitive ideals of science knowledge, rather than the messy everyday reality of how the institutions of science, including science education, work with and within other bases of society power, to privilege some, and disadvantage others (Boyd, 2001). In these discussions, exactly what is meant by the word 'science' comes into play, a notoriously difficult question to adequately and succinctly answer (Chalmers, 1999). Again the disconnection of philosophy of science from the school science curriculum impedes the debate. There is, of course, a distinction between working science and what is often called 'school science' - the knowledge base of the science curriculum - which is presented and enacted with many different emphases and variations in each individual classroom.

As it has for many decades, the triad of Biology, Chemistry and Physics still represents the world of contemporary science in the school curriculum (Aikenhead, 2000). It is widely acknowledged that the school science curriculum is a simplistic representation of the knowledge base of the world of science, or school science: clearly, simplification is appropriate and necessary. But the question remains of whether or not school science is a distorted representation of the knowledge base of science; and, if so, the nature and extent of those distortions, the supporting processes and effects, and the possibility of amelioration (Blades, 1997). To the extent that such distortions are based on particular ideas, including racist, sexist or other unscientific ideas, they may have an inadvertent alienating effect on some groups of students more so than others.

It therefore warrants considering whether residues of colonial Eurocentrism remain in Science in the New Zealand Curriculum, given the differential alienating effect this may exert on Māori students as a population, compared with the total student population. As noted above, the statistical literacy and numeracy gaps for Māori account for a large part of the gap in Māori science outcomes. But even those senior Māori students who achieve well in other subjects mostly reject senior science subjects. Teachers of senior Chemistry, Physics and Biology tend to have fewer Māori students in their classes than their school colleagues teaching English or Mathematics (McKinley, 2008). The above graphs fail to reveal the extremely limited participation by Māori in Level 3 NCEA Mathematics and Science compared with the 'EE' group. Most Māori students have left school by the end of Year 12, and those who remain are seldom found in senior science classes: more often in arts, technology or health and physical education.

One important and relevant science distortion is the now-discredited belief that Māori are an inherently inferior type of people, by comparison with British or European people (McKinley, 2001, 2003). This belief is built into the concept of 'race' as still used in some domains, notably in the United States of Americ, despite having been expunged long ago from the canons of science. 
Unfortunately this key idea was a potent item of scientism, or scientific racism, employed in the modernist history of British colonisation of this country (Stenhouse, 1999). It is only a small step from acknowledging the key role played by the British Empire in the development of modern science, to the old idea about European superiority and, even if only by implication, Māori inferiority (Wetherell \& Potter, 1992). Experts and scholars in the field often get the arguments about Māori science wrong (Stewart \& Buntting, 2015), so science teachers with the usual lack of background in philosophy of science must be forgiven for failing to appreciate the need to clearly differentiate between these two ideas.

By not making explicit its underlying philosophies at any point, from teacher training to school qualifications, science education is vulnerable to the ongoing influence of such insidious 'hidden' distortions and gaps (Sammel, 2008). These implicit influences are an example of the 'hidden curriculum'-a term for that which is inadvertently taught and learned in every classroom, yet never discussed in texts or pedagogical dialogue (Rahman, 2013). Science teachers and curriculum policies default to a position that science is 'the truth': universal and unrelated to culture; and that students including Māori students 'need' science knowledge to 'succeed'. While operating from these beliefs, teachers are blinded or blind themselves to the limits of science knowledge, the politics of science, and the entanglement of science with past and present racialised views of the world. Leaving out these peripheral aspects seems pedagogically sound to a teacher intent on 'covering the curriculum' or 'helping the students', but may be received, particularly by Māori students, as arrogance and lack of cultural intelligence.

Motivated by equity concerns for students from non-dominant cultures, a vast amount of scholarship has been written about multicultural science education (McKinley, 2005). Inclusion of indigenous knowledge (IK) in the science curriculum has been popular, in debates analogous to 'Māori science' in Aotearoa New Zealand, and IK has even been mandated as compulsory in the science curriculum in parts of Canada (Aikenhead \& Michell, 2011). Yet the predilection of science with 'facts' and the invisibility of philosophy in science education mean such attempts are doomed from the start, and in practice miss their mark, since it is at the philosophical and ethical levels, which are excluded from school curricula and qualifications, that science needs to learn from IK. There have been no reports of significant, sustained improvement in science outcomes for populations of Māori or indigenous students anywhere, as a result of including IK in the science curriculum.

Relativist philosophies of knowledge are important in Māori science education at the levels of identity and language, in both English-medium and Māori-medium schools, albeit with characteristic differences between the two systems. In the interests of Māori students in both types of school, mainstream or English-medium science education needs to embrace a bit of relativism, while Pūtaiao or Māori-medium science education needs to wake up to the importance of universalism. Rather than argue over relativism in relation to science curriculum content knowledge, all might benefit from recognising that Māori science education encapsulates both relativist philosophies of cultural identity and language, and the need to master universalist science knowledge and language, and that this is a built-in or permanent contradiction that must be lived with, not stamped out or ignored by either side. 


\section{POLICY EFFECTS OF THE MĀORI SCIENCE NEXUS}

Bilingualism and biculturalism in education including Kaupapa Māori education are based on relativist attitudes towards language and culture, but the language and culture of the vast majority of schools nationally is still normatively English/Pākehā (McKinley, 2007; McKinley \& Keegan, 2008). In Māori-medium schooling, the Māori identity of the school largely takes care of the identity problems suffered by Māori students in most English-medium schools, particularly in secondary schools. In practice, mainstream science teachers, especially of Year 9 and 10 Science often 'tick the Treaty box' (Papesch, 2006) by using emblematic Māori topics-"caricatures of culture"-to show their commitment to equity and the Treaty of Waitangi (McKinley, 2008, p. 31). Meanwhile, in Māori-medium, the development of Pütaiao continues firmly down the translation pathway, with little apparent attention being paid to its actual benefits or otherwise. Ironically, the dominance of the translation approach means there is less opportunity, motivation or need to include Māori content in Pütaiao than in mainstream science programmes.

The notion of 'Māori science' creates a crisis in science education because it is anathema to the universalist knowledge commitments of science, yet it has strong political appeal as an apparently powerful response to equity policy and the Treaty of Waitangi. Even more seductive is the related or 'proxy' idea of translating science into Māori. The popularity of the translation idea among science teachers is understandable, given the intransigence of the achievement gap for Māori in science education, and the lack of other options. Translation seems to offer an ideal way to bring together the science and Māori worlds. Translation is also a concrete task with tangible products, which appeals to the spirit of managerialism and technocratic rationality that reigns in today's world of visible outputs and accountability.

Yet translation is never a neutral apolitical process: it is an ideology that yokes together power, education and culture, given the importance of language in cultural and ethnic identities (Blommaert, 1999). In Māori science education, some may argue that Kaupapa Māori principles demand the 'Māori-only' approach, but this argument falls prey to 'linguistic purism' that includes rejection on principle of English (Harlow, 2005) including rejection of bilingualism. But the principles of Kaupapa Māori are not a 'check-list' and cannot be reduced to a brute criterion of language medium, which rests on black-and-white attitudes such as 'Māori good, English bad'. This purist Māorionly position inevitably becomes self-defeating in Māori-medium science education (Stewart, 2012), in the sense of working against the larger interests of the students and whānau. Previously I have discussed language purism and its effects in Pūtaiao in detail (Stewart, 2010a, 2010c).

To argue that Kaupapa Māori principles demand critique of the 'Māorionly' approach to Pūtaiao education invokes the description of methodology in the introduction section above. Kaupapa Māori principles are important in guiding all decisions, including pedagogical decisions, in Māori-medium schooling. The original NZCER report (Bull, Gilbert, Barwick, Hipkins, \& Baker, 2010) that Sir Peter Gluckman commissioned when he undertook his evaluation of national science education emphasised that science teaching and learning in primary classrooms is qualitatively different from science teaching and learning in secondary classrooms. I argue this difference is essentially a difference in the 
nature of language used in the primary science classroom compared with the secondary classroom, as discussed by linguists such as Michael Halliday (2004; Halliday \& Martin, 1993). Accordingly, it makes sense to consider that the language of Pūtaiao for primary classrooms may need to be qualitatively different from Pūtaiao language for secondary classrooms. Te reo Māori will always be central in Māori-medium education, but proficiency in Māori will not suffer if students learn bilingually in secondary Pūtaiao classrooms.

My opposition to Māori-only Pūtaiao language policy reinforces the concerns of Gluckman cited at the start of the article. To translate school science into an endangered indigenous language such as Māori is a particularly fraught undertaking, yet the support base for this approach appears to be widening as time goes on, not only within the Māori-medium sector but also amongst English-medium or mainstream science educators. For maximum clarity, the arguments I have presented for and against the translation approach as 'science in Māori-only' are summarised below.

\section{SUMMARY OF BENEFITS AND LIMITATIONS OF 'SCIENCE IN MĀORI'} Māori:

There are three perceived benefits of translating science into te reo

1. Do-able: as noted above, it is a concrete task with a tangible output;

2. Obviously 'Māori' since it is written in Māori text;

3. Obviously 'science' since it is a translation i.e. it 'means' the same.

But opposing views for this triplet highlight the limitations of translating science into Māori:

1. Outputs are of dubious value since vanishingly few students learn science in Māori (due at least in part to the two factors below); anecdotal evidence suggests existing resources are not being used;

2. The quality of Māori language produced by translating science is unlike traditional forms of te reo me ōna tikanga; furthermore, the emphasis on translation means there is less motivation or opportunity to consider science from Māori perspectives or traditional Māori knowledge of the natural world.

3. The quality of science text produced is arguably poor, since these translations will never be perfect, and past a certain level of cognitive complexity, back-translations seldom return to the original set of mearnings, and are certainly impoverished by comparison with Englishmedium science education. Teaching, reading and writing science in Māori is more difficult than in English due to language features: not only vocabulary limitations but also syntax and oral features of te reo Māori impede comprehension and make it harder to teach and learn. 
Science language has developed as a specialist register within English over several centuries and English is now the overwhelmingly dominant language of science. The whole amount spent on education in this country would not suffice to provide a complete science lexicon in te reo Māori: it is clearly not something that can be achieved by a few contracts and curriculum projects.

Left at an impasse by this set of opposing perspectives, the way through is surprisingly close at hand: a subtle but deeply significant opening up of the meaning of 'Pūtaiao' from Māori-only to include bilingual science.

\section{BILINGUAL SCIENCE: UNTAPPED POTENTIAL, PRAGMATIC WORKAROUND, OR BOTH?}

At first glance it may seem a fine distinction from the 'science in Māori' approach, but one option for resolving the question of Māori science education is bilingual science, which offers benefits over the translation approach on both theoretical and practical levels. The term 'bilingual science' is variable since in theory it can range from $1-99 \%$ of each language. Something simple like a crossword made using Māori items of vocabulary related to the current science topic is an easy place to start. The cross-fertilisation and benefits for classroom practice are self-evident. Items from the small but steadily growing list of reo Māori science posters and books can be used and placed in the classroom library. Every booklet in the Building Science Concepts series includes a list of Māori vocabulary (Building Science Concepts series, scienceonline.tki.org.nz/What-do-my-students-need-to-learn/Building-Science-

Concepts/About-the-series), though new resources including online comprehensive dictionaries are available (e.g. Wakareo). Science and te reo Māori are both challenging areas for primary teachers, who are required to strongly focus on literacy and numeracy, but bilingual science addresses both science and te reo simultaneously.

It is relevant here to refer to my recent article on the use of te reo Māori in classrooms (Stewart, 2014b). There, I challenged classroom teachers to ensure that the children they teach are empowered to use and build on the Māori language knowledge they may bring from home or from previous educational experiences. In terms of pedagogical challenges, there are similarities between science and te reo in the primary classroom: both involve learning new language and ideas, unfamiliar to many lay adults and teachers alike; both lend themselves to field trips and classroom visitors; and in both cases, students can and (I would argue) should undertake their own research projects, by which possibly to outstrip their teacher's knowledge and literacy. Further discussion of this 'bilingual science' approach is beyond the scope of this article, but it warrants fleshing out in future work.

\section{WHAT CAN TEACHERS DO ABOUT MĀORI SCIENCE EDUCATION?}

Firstly, teachers should not accept blame for what is not in their control. The problem of Māori science education outcomes is large and difficult to address: there are no magic bullets. Reported successes to date are usually 
due to a 'hero' teacher: an individual with the passion, resources and combination of skills to design an engaging programme and make it work (e.g. see Education Gazette, 2009).

Research aiming at culturally responsive pedagogy in science education has offered little specific advice to teachers of science, beyond "affirming and acknowledging" the knowledge bases and experiences of Māori students, which might reasonably be assumed already part of good teaching practice in any classroom (Glynn et al., 2010, p. 126).

Secondly and relatedly, teachers who wish to make a difference for Māori students in science education need to undertake further study in two areas: the history and philosophy of science; and the history of colonisation of Māori. Encompassing science, education, language and culture, the topic of Māori science education is connected to a vast amount of literature. Each individual teacher may start from a different place and be interested in different aspects, which makes it impossible to give a definitive list of recommended readings. My previous publications and those by Elizabeth McKinley that are listed in the references at the end of this article provide a starting point for teachers who wish to follow this path. There is also undoubtedly the need to extend the discussions in this article in future work.

Thirdly, both English- and Māori-medium teachers of science are encouraged to consider the possibilities bilingual science offers for their own classroom, as discussed in the preceding section above.

\section{CONCLUSION}

Given that it is impossible for classroom teachers to change the systemic inequalities of socioeconomic privilege and relative disadvantage that structure the lives of their students, the task of ameliorating Māori underachievement in school science is a formidable challenge. Yet all teachers are held accountable for responding to the needs of their Māori students; hence the ongoing popularity of including emblematic 'Māori science' topics in the classroom programme (McKinley, Stewart, \& Richards, 2004).

Gluckman's challenge points to the real crisis: the widespread support for translating science into Māori-only suggests this approach is increasingly being seen as providing the 'answer' to the problem of inequity in Māori science education outcomes. National policy for Pūtaiao has become unhooked from the situation on the ground in kura, ensuring Smith's prediction would fail. Fueled by linguistic purism, translating science into Māori-only consumes the very limited resource available for Māori science education. If mainstream science educators uncritically accept this orthodoxy of translating science into Māori-only, then Pūtaiao is at risk of being a distraction from the wider interests of Māori students in both English- and Māori-medium schools. To widen the policy to include 'bilingual science' especially at secondary levels offers a possible option for moving forward 'from here' for both English- and Māorimedium science education. Though more detailed discussion must await future work, my sense is that bilingual science offers real possibility for engaging the productive binary of interculturalism in Kaupapa Māori science education. As it is, the flawed assumption that science can be unproblematically translated at any level into te reo Māori, and more easily and successfully taught and learned 
in te reo than in English, is indeed causing a policy crisis in Māori science education.

\section{ACKNOWLEDGEMENTS}

1. Acknowledgement and thanks to Ally Bull for helpful discussions and support in writing this article.

2. Acknowledgement and thanks to Starpath for permission to use the NCEA graphs.

3. Acknowledgement and thanks to NZCER for permission to use the data from Competent Learners @14.

Manuscript Submitted: January 14, 2017

Revised Manuscript Received: March 23, 2017

Revised Manuscript Accepted: March 23, 2017 


\section{REFERENCES}

Aikenhead, G. (2000). Renegotiating the culture of school science. In R. Millar, J. Leach, \& J. Osborne (Eds.), Improving science education - the contribution of research (pp. 245-264). Buckingham, PA: Open University Press.

Aikenhead, G., \& Michell, H. (2011). Bridging cultures: Indigenous and scientific ways of knowing nature. Ontario, Canada: Pearson Education.

Bevilacqua, F., Giannetto, E., \& Matthews, M. R. (Eds.). (2001). Science education and culture: The contribution of history and philosophy of science. Dordrecht, The Netherlands: Kluwer Academic Publishers.

Blades, D. W. (1997). Procedures of power and curriculum change: Foucault and the quest for possibilities in science education. New York, NY: Peter Lang Publishing Inc.

Blommaert, J. (Ed.). (1999). Language ideological debates. Berlin, Germany/New York, NY: Mouton De Gruyer.

Boyd, R. N. (2001). Reference, (in)commensurability \& meanings: Some (perhaps) unanticipated complexities. In P. Hoyningen-Huene \& $\mathrm{H}$. Sankey (Eds.), Incommensurability and related matters (pp. 1-63). Dordrecht, The Netherlands: Kluwer.

Bull, A., Gilbert, J., Barwick, H., Hipkins, R., \& Baker, R. (2010). Inspired by science. Wellington, New Zealand: New Zealand Council for Educational Research.

Carpenter, V., \& Osborne, S. (2014). Twelve thousand hours: Education and poverty in Aotearoa New Zealand. Auckland, New Zealand: Dunmore.

Chalmers, A. F. (1999). What is this thing called science? (3rd ed.). St Lucia, QLD, Australia: University of Queensland Press.

Dickison, M. (1994). Māori science? Can traditional Māori knowledge be considered scientific? New Zealand Science Monthly, 5(4), 6-7.

Duschl, R. (1985). Science education and philosophy of science twenty-five years of mutually exclusive development. School Science and Mathematics, 85(7), 541-555.

Education Gazette. (2009). Science and te ao Māori. Retrieved from www.edgazette.govt.nz/Articles/Article.aspx?Articleld=7924

Ellis, C., \& Bochner, A. P. (2000). Autoethnography, personal narrative, reflexivity. In N. K. Denzin \& Y. S. Lincoln (Eds.), Handbook of qualitative research: second edition (pp. 733-768). Thousand Oaks, CA: Sage.

Gluckman, P. (2011). Looking ahead: Science education for the twenty-first century. A report from the Prime Minister's Chief Science Advisor. Auckland, New Zealand: Office of the Prime Minister's Science Advisory Committee. Retrieved from http://www.pmcsa.org.nz/wpcontent/uploads/Looking-ahead-Science-education-for-the-twenty-firstcentury.pdf.

Glynn, T., Cowie, B., Otrel-Cass, K., \& Macfarlane, A. (2010). Culturally responsive pedagogy: Connecting New Zealand teachers of science with their Māori students. The Australian Journal of Indigenous Education, 39, 118-127. doi:10.1375/S1326011100000971

Halliday, M. A. K. (2004). The language of science. London, England/New York, NY: Continuum. 
Halliday, M. A. K., \& Martin, J. R. (1993). Writing science: Literacy and discursive power. London, England/New York, NY: Routledge.

Harlow, R. (2005). Covert attitudes to Māori. International Journal for the Sociology of Language, 172, 133-147.

Honderich, T. (Ed.). (1995). The Oxford companion to philosophy. Oxford, England: Oxford University Press.

Locke, T. (2004). Critical discourse analysis. New York, NY/London, England: Continuum.

Lomax, T. (1996). Māori science revisited. NZ Science Monthly, 7(6), 12-13.

McKinley, E. (2001). Cultural diversity: Masking power with innocence. Science Education, 85(1), 74-76.

McKinley, E. (2003). Brown bodies, white coats: Postcolonialism, Māori women and science (Unpublished Doctor of Philosophy thesis). University of Waikato, Hamilton, New Zealand.

McKinley, E. (2005). Locating the global: Culture, language and science education for indigenous students. International Journal of Science Education, 27(2), 227-241.

McKinley, E. (2007). Postcolonialism, indigenous students, and science education. In S. K. Abell \& N. G. Lederman (Eds.), Handbook of research in science education (pp. 199-226). Mahwah, NJ/London, England: Lawrence Erlbaum Associates.

McKinley, E. (2008). Māori in science and mathematics education. In J. S. Te Rito \& S. M. Healy (Eds.), Te Ara Pūtaiao: Māori insights in science (pp. 27-36). Auckland, New Zealand: Ngā Pae o te Māramatanga. Retrieved from

http://www.maramatanga.ac.nz/sites/default/files/TO\%20Te\%20Ara\%20 P\%C5\%ABtaiao\%20Maori\%20scientists.pdf

McKinley, E., \& Keegan, P. (2008). Curriculum and language in Aotearoa: From Science to Pūtaiao L1- Educational Studies in Language and Literature, 8(1), 135-147.

McKinley, E., McPherson Waiti, P., \& Bell, B. (1992). Language, culture and science education. International Journal of Science Education, 14(5), 579 $-595$.

McKinley, E., Stewart, G., \& Richards, P. (2004). Māori students in science and mathematics: Junior programmes in secondary schools. set: Research for teachers, 2004(3), 9-13.

Osborne, R., \& Freyberg, P. (1985). Learning in science: The implications of children's science. Auckland, New Zealand: Heinemann.

Papesch, T. R. (2006). Kapa Haka. In M. Mulholland (Ed.), State of the Māori nation (pp. 33-39). Auckland, New Zealand: Reed Books.

Peters, M. A. (2011). The last book of postmodernism. New York, NY: Peter Lang.

Pipi, K., Cram, F., Hawke, R., Hawke, S., Huriwai, T., \& Mataki, T. (2004). A research ethic for studying Māori and iwi provider success. Social Policy Journal of New Zealand, 23, 141-153.

Rahman, K. (2013). Belonging and learning to belong in school: the implications of the hidden curriculum for indigenous students. Discourse: Studies in the Cultural Politics of Education, 2013, 34(5), 660-672. doi:10.1080/01596306.2013.728362 
Sammel, A. (2008). Traveling with and through your backpack: a personal reflection on the infrastructure of science education. Cultural Studies of Science Education, 3, 843. doi:10.1007/s11422-008-9118-9

Smith, G. H. (1995). Falling through the cracks of the constructivism debate: the neglect of the Māori crisis within science education. ACCESS - Critical Perspectives on Cultural and Policy Studies in Education, 13(2), 103121.

Smith, L. T. (2012). Decolonizing methodologies: Research and indigenous peoples (2nd ed.). London, England/Dunedin, New Zealand: Zed Books.

Stenhouse, J. (1999). Darwinism in New Zealand. In R. L. Numbers \& J. Stenhouse (Eds.), Disseminating Darwinism (pp. 61-89). Cambridge, England: Cambridge University Press.

Stewart, G. (2005). Māori in the science curriculum: Developments and possibilities. Educational Philosophy and Theory, 37(6), 851-870.

Stewart, G. (2007). Kaupapa Māori science. Unpublished doctoral thesis in Education, Waikato University, Hamilton.

Stewart, G. (2010a). Good science? The growing gap between power \& education. Rotterdam, The Netherlands: Sense.

Stewart, G. (2010b). Knowing our place: Critical multicultural science education. In S. May \& C. Sleeter (Eds.), Critical multiculturalism: Theory and praxis (pp. 151-162). New York, NY/London, England: Routledge.

Stewart, G. (2010c). Language issues in Māori chemistry education. AlterNative, 6(1), 66-71.

Stewart, G. (2011a). The extra strand of the Māori science curriculum. Educational Philosophy and Theory, 43(10), 1175-1182.

Stewart, G. (2011b). Science in the Māori-medium curriculum: Assessment of policy outcomes in Pūtaiao education. Educational Philosophy and Theory, 43(7), 724-741.

Stewart, G. (2012). Achievements, orthodoxies and science in Kaupapa Māori schooling. New Zealand Journal of Education Studies: Te Hautaka Matai Matauranga, 47(2), 51-63.

Stewart, G. (2014a). The Māori body in education: From 'good with their hands' to the 'long brown tail'. In P. O'Connor \& K. Fitzpatrick (Eds.), Education and the body (pp. 11-21). Auckland, New Zealand: Edify.

Stewart, G. (2014b). Te reo Māori in classrooms: Current policy, future practice. set: Research information for teachers, set2014(3), 3-7.

Stewart, G. (2015). Ethnoscience. In R. Gunstone (Ed.), Encyclopedia of science education (pp. 401-402). Dordrecht, The Netherlands/Heidelberg, Germany/New York, NY/London, England: Springer. doi:10.1007/978-94-007-2150-0

Stewart, G. (2016). Indigenous philosophies and education: The case of Kaupapa Māori. EEPAT Encyclopaedia of Educational Philosophy and Theory.

Retrieved from http://link.springer.com/referenceworkentry/10.1007/978-981-287-5327 177-1 doi:10.1007/978-981-287-532-7_177-1

Stewart, G., \& Buntting, C. (2015). Teachers, curious minds, and science education. Curriculum Matters, 11, 98-116.

Wetherell, M., \& Potter, J. (1992). Mapping the language of racism: Discourse and the legitimation of exploitation. New York, NY: Harvester Wheatsheaf. 
Wylie, C., \& Hipkins, R. (2006). Growing independence: Competent Learners @14. Wellington, New Zealand: Ministry of Education. 
ABOUT THE AUTHOR

\section{GEORGINA STEWART}

AUT University

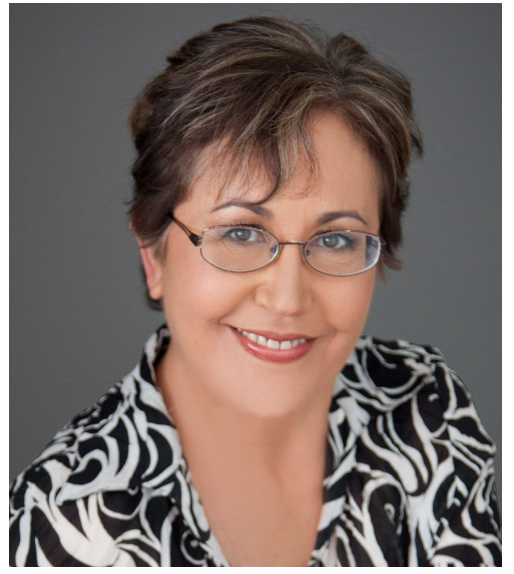

Georgina Stewart (ko Whakarārā te maunga, ko Matauri te moana, ko Ngāti Kura te hapū, ko Ngāpuhi-nui-tonu te iwi) is a senior lecturer in $\mathrm{Te}$ Kura Mātauranga School of Education, AUT University in Auckland. Previously she taught science, mathematics and te reo Māori in intermediate and secondary schools, and in her doctoral work investigated the Māori science curriculum. Her research explores various aspects of the philosophical nexus between language, knowledge, culture and education. 